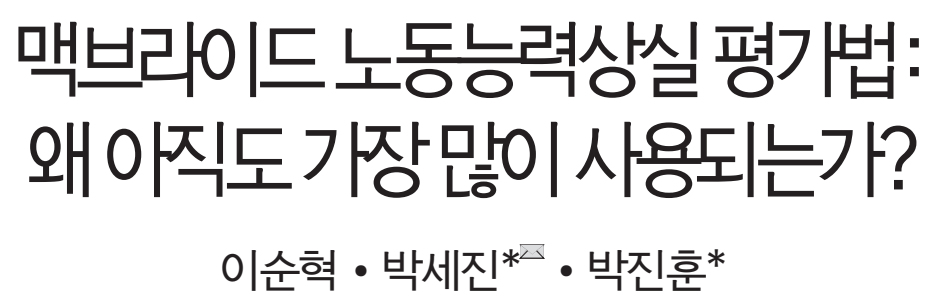

고려대학교 의과대학 고려대학교 안암병원 정형외과학교실,

*성균관대학교 의과대학 강북삼성병원 정형외과학교실

\title{
McBride's Disability Assessment: Why Is It Still Most Used?
}

\author{
Soon-Hyuck Lee, M.D., Se-Jin Park, M.D. ${ }^{\star \star}$, and Jin Hun Park, M.D.* \\ Department of Orthopaedic Surgery, Korea University Anam Hospital, Korea University College of Medicine, \\ ${ }^{*}$ Department of Orthopaedic Surgery, Kangbuk Samsung Hospital, Sungkyunkwan University School of Medicine, Seoul, Korea
}

The task of defining the concept of 'disability' has proven to be surprisingly difficult. The way disability is assessed in the world suggests that very different conceptions of disability are being presumed. It is very hard to suggest appropriate criteria for assessing a disability that accurately demonstrates the presence and measures the severity of the disability, with proven consistency and validity provided by the assessors consuming the time and cost that the society can afford. When a rigorous framework in disability assessment procedures is used, discretion is then considerably restricted. Limited discretion tends to produce more consistency and validity in the assessment but at the cost of ignoring the individual differences or exceptional circumstances. The disability approach among the categories of the disability assessment is both the oldest and the most commonly used strategy of disability assessment around the world. Most of the criteria of disability assessment in Korea belongs to this. The McBride's criteria for disability evaluations can be used to obtain the ratio of body impairment and work disability without spending too much time and is being applied in court. Nevertheless, there are many errors and controversies, and corrections are required. On the other hand, an improvement plan for a disability evaluation method in Korea is to supplement and use the McBride's disability assessment method, which is currently the most widely used. This review article describes the conception of disability and the assessment of disability, and introduces the models of the assessment of disability to determine if the application of the McBride's criteria of disability evaluation can be justified.

Key words: McBride's criteria, reparation, disability, assessment of disability

\section{서 론}

장애판정에 가장 결정적인 역할을 하는 장애평가는 의료 전문가 에게 그 권한과 책임이 있는데, 이때 기준이 되는 장애평가 방법 자체에 문제가 있을 수 있어 적절한 장애평가 방법을 확립하는 것이 중요한 출발점이다.

\footnotetext{
Received July 18, 2020 Revised August 16, 2020 Accepted September 8, 2020 Correspondence to: Se-Jin Park, M.D.

Department of Orthopaedic Surgery, Kangbuk Samsung Hospital, Sungkyunkwan University School of Medicine, 29 Saemunan-ro, Jongno-gu, Seoul 03181, Korea TEL: +82-2-2001-2168 FAX: +82-2-2001-2176 E-mail: qortn97@naver.com ORCID: https://orcid.org/0000-0002-3941-1857
}

현재 한국에서 배상이나 보상을 위한 여러 장애평가 기준이 목 적에 따라 사용되고 있다. 이 중에서 맥브라이드의 노동능력상실 평가법은 현재 법원에서 신체장해로 인한 노동력 상실을 산정에 사용하고 있는데, 발표 시기가 50여 년 전이어서 현재의 의학적 수준과 분명한 차이가 있으며, 여러 제한과 한계가 있다는 데 공 감을 얻고 있는 상황이다. 이에 대처하여 약 15 여 년 전부터 새로 운 장애평가 기준을 제시하려는 시도가 대한의학회 및 대한정형 외과학회에서 있었으나 현재까지 사용되고 있지 않다.

대한정형외과학회에서는 현재 사용되고 있는 맥브라이드 평가 방법에서 발견된 오류를 수정하고, 현대의 의학적 수준에 합당한 평가가 가능하도록 변경하며, 여러 제한과 문제점을 개선하고자 
McBride’s Disability Assessment

한다. 맥브라이드의 노동능력상실 평가법이 가지고 있는 여러 한 계에도 계속 사용하는 것이 적절한지에 대한 의문이 있을 수 있 다.

이 논문에서는 먼저 장애와 장애평가에 대한 기본적인 내용을 소개하고자 한다. 또한 장애의 개념과 장애평가 방법에 대한 다 양한 종류와 견해, 각각의 장단점을 소개하면서 맥브라이드의 노 동능력상실 평가법이 아직도 유용하게 사용될 수 있는 당위성에 대하여 알아보고자 한다.

\section{장애에 대한 이해}

\section{1. 장애의 국가별 차이}

그리스-로마 시대에 아테네에서는 장애인에게 공적 지원을 제공 하였고, 로마법에는 장애인의 구체적 권리를 열거하였으나 스파 르타에서는 신체 기형인 영아 살해의 기록이 있어 장애인에 대한 관점이 다를 수 있음을 보여준다.

$\mathrm{WHO}$ 가 59 개 국가의 평균 장애 출현율을 도출한 결과 $15.6 \%$ 로 추정되는데, 고소득 국가에서는 $11.8 \%$, 저소득 국가에서는 $18 \%$ 로 추정되었다. ${ }^{1)}$ 그러나 국가별 등록 장애자의 비율은 국가 에 따라 큰 차이를 보여 우리나라의 경우 2010년 이후 전체 인구 대비 약 $5 \%$ 가 지속적으로 등록되고 있고, 일본 $5 \%$ 대, 스페인, 이 탈리아는 $8 \%$ 대, 미국 $12 \%$, 네덜란드, 독일, 덴마크는 $13 \%-15 \%$, 스위스, 오스트리아, 노르웨이, 프랑스, 뉴질랜드, 이스라엘은 $17 \%-25 \%$ 로 큰 차이를 보이고 있다. 이는 장애의 정의와 범주는 그 나라의 사회 문화적·경제적·정치적 여건과 수준에 따라서도 다를 수 있고 장애를 보는 관점에 따라서도 상이해질 수 있기 때 문이다.

\section{2. 장애의 개념 및 분류 \\ 1) 장애의 개념}

장애의 개념으로 의료 모델은 장애를 본질적으로 개인의 신체에 위치한 의학적 문제로 보았다. 이와 대조적으로 사회적 장애 모 델은 장애가 근본적으로 사람의 신체 상태의 문제가 아니라 사회 적, 문화적, 경제적 조건과 편견으로 인하여 발생하는 사회적 불 이익이라고 하였다.

1970년대 이후로, 의료 모델과 사회적 모델이라는 두 가지 극 단적 장애 모델 사이에서 논란이 지속되고 있었다. 그러나 최근 에는 컨센서스 관점 또는 '상호작용 모델'이 제시되었는데 이는 장애가 개인의 신체와 마음의 본질적인 생물학적 또는 건강 특징 과 그 사람이 생활하고 경험하는 환경과의 복잡한 상호 작용의 결과로 일어나는 다차원 현상으로 인해 발생되는 것으로 보는 것 이 현재의 주도적인 견해이다. ${ }^{2}$

장애가 신체 상태와 환경 상태 모두에 영향을 받는다는 것을 아무도 부인하지는 않아 상호작용 장애 모델이 현재는 일반적으
로 받아들여지고 있지만 구 모델, 특히 의료 모델은 중요하게 사 용되고 있다. 이를 보면 현재 전 세계 국가에서 장애에 대한 개념 과 실제 장애가 평가되는 방식에는 큰 괴리가 있음을 알 수 있다.

\section{2) 장애의 분류 및 용어}

1980년에 $\mathrm{WHO}$ 에서 최초로 장애 개념을 체계화하여 분류 체계 인 ICIDH (International Classification of Impairments, Disabilities and Handicaps)를 제시하였다.3) 여기에서 “질병(disease)"은 신체적, 심리적 손상으로 신체구조의 변화를 일으켜 병 리적인 상태가 외재화된 “신체 손상(impairment)"을 일으키고, 이는 일상생활에서 수행하는 능력의 제약인 “능력 장애(disability)"를 야기하며 이로 인하여 사회문화적 수용 정도에 따른 정상 적인 역할의 수행을 방해하는 개인에 대한 불이익인 “사회적 불 리(handicap)"가 일어나는 세 가지 측면이 있다고 용어와 개념 을 소개하였다. 이 개념은 아직도 세계보건기구, 미국사회보장법 과 미국의학협회(American Medical Association, AMA)의 신 체장애와 능력상실의 정의로 널리 사용되고 있다.

그러나 이 분류 체계에 대한 여러 문제점과 한계가 있어 1997 년 세계보건기구(World Health Organization, WHO)는 ICIDH-2를 발간하였다. 질환이 있는 개인이 접하게 되는 장애 를 손상(impairment), 활동(activities), 참여(participation)로 구분하였고 장애는 환경과 개인이라는 상황적 요인을 포함하였 다.

그럼에도 이 분류에 여러 문제점이 지적되어 2001년 $\mathrm{WHO}$ 는 ICF (International Classification of Functioning, disability and health)를 발간하였다. ${ }^{5)}$ 용어가 주는 부정적인 인상을 중 립적인 신체구조 이상(body structure), 활동(activities limitation), 참여(participation)로 바꾸었다. ICF는 장애가 신체의 이 상에 의해서만 생기는 것이 아니라 사회적 차별이 중요하다는 인 식과 신체적 장애의 측면보다는 기능적 장애의 측면을 강조하고, 보편적 시각에서 접근하여 장애 그 자체보다는 그로 인한 건강과 활동 수준에 역점을 두어 설계되었다. 그러나 이러한 제안에 대 하여 논란이 있고 현실성이 부족하여 실제 사용은 아직 제한적이 다.

\section{장애평가의 이해}

\section{1. 장애평가란 무엇인가?}

장애평가(assessment of disability)는 일반적으로 개인이 가지 고 있는 장애의 종류와 정도에 대한 권위 있는 결정과정의 하나 로서 법원, 행정기관, 보험회사의 장애판정 또는 장애결정(determination or evaluation of disability)이라고 하는 더 큰 범 위의 행정 절차의 한 부분이다. 
Soon-Hyuck Lee, et al.

\section{2. 장애평가 분류}

\section{1) Brunel 대학 분류)}

의학적 관점에 중점을 두었는지 평가자에게 얼마나 재량권을 주 었는지 두 가지 관점에서 분류하고 있다. 의학적 관점을 강화할 수록 평가에 비용이 더 드는 것이 일반적이다.

장애평가에 엄격하고 자세한 규격을 사용하면 평가자의 재량 권이 제한된다. 이는 평가에서 일관성과 평가자 간 신뢰도를 높 이지만 개별적인 차이나 예외적인 상황을 무시하게 된다. 반면 평가자의 재량권이 크면 일관성과 신뢰성이 저하된다. 장애에 대 한 개념의 논란, 장애평가 규격이 가지는 본질적 한계가 있어 엄 격하고 자세한 규격이 최선의 방법이라는 데에는 이견이 있다.

\section{2) 장애평가 대상에 따른 구분}

장애평가 방법은 주 관심 대상에 따라 (1) 손상 접근 방식, (2) 기 능 제한 접근법, (3) 장애 접근 방식으로 구분하고 있다. ${ }^{2)}$

(1) 손상 접근법(impairment approach)

노동능력의 평가를 전적으로 내재된 건강 상태와 관련되어 나타 나는 손상의 정도를 측정하는 방식이다. 이 방식은 단순하고 간 단하며, 지금까지 가장 널리 사용되는 접근법이지만 업무 환경의 특성을 고려하지 않은 상태에서 신체 장애로 인한 제한이 노동 능력 정도를 적절히 반영한다는 가정과 기술적으로 적절한 신뢰 도가 있는지에 대해 모두 비판을 받아왔다. 이 방법은 Baremas 평가방법과 밀접한 관계가 있는데, 이는 신체 손상의 종류와 정 도에 따라 순차적으로 백분율 값을 임의의 상대 척도로 하여 장 애율 표로 장애 수준을 결정하는 방법으로 나중에 비스마르크 모 델로 알려졌다. 이 방법의 가장 정교하고 복잡하게 발전된 형태 가 $\mathrm{AMA}$ 의 “영구적 신체장애평가지침"이다. 그러나 이것조차도 의학적 증거 기반 없이 전문가의 합의에 전적으로 의존하는 데에 서 오는 장애 등급의 불일치와 모호성, 장기 시스템 간의 일관성 부족, 기능적 등급의 반영 실패, 신뢰성 부족 및 예측 능력 부재에 대하여 비판을 받고 있다.

여러 비판에 대한 반론으로 첫째, 장애와 노동능력 상실을 연 결하는 최적 표준이란 것이 없으므로 전문가의 합의 방법론이 최 선의 방법이고, 둘째, 장애와 신체손상과는 다르지만 보다 복잡 한 장애평가의 유용한 단계이며, 셋째, 행정적으로 실행 가능하 며 정책적 요구사항을 충족시키는 것이 가능하므로 매우 유용하 다고 하였다.

실제적으로 다른 방법에 의한 평가는 충분한 의학적 정보를 얻 기가 어렵고, 또한 감정인의 주위 환경에 관한 모든 정보를 얻어 취합하여 평가한다는 것이 불가능하기 때문에 비용과 효과 측면 에서 보면 국가적 평가방법으로 손상 접근법이 현재는 현실적인 유일한 방법으로 볼 수 있다.

(2) 기능 제한 접근법(functional limitation approach)

이 접근방식은 1970 년대에 시작되었는데, 사람의 업무 능력은
그 사람이 매우 기본적인 행동을 할 수 있는 정도에 달려 있다고 하였다. 이러한 ‘기능적 역량’이 작업 능력 예측에 필수적이라고 여겼다. 이러한 ‘기능적 역량'을 평가하기 위해 다양한 기능 능력 평가(Functional Capacity Evaluation, FCE) 도구가 개발되고 장애평가를 위해 사용이 권장되었다. 그러나 유효하고 신뢰할 수 있는 FCE 도구의 개발 결과가 실망스럽다고 알려졌고 이 방법 역시 손상 접근법과 동일한 문제, 즉 간접적으로만 작업능력 정 도(work capacity)를 평가한다는 한계가 있다.

(3) 장애 접근법(disability approach)

이는 신체장애나 기능 능력 평가를 통해 장애를 간접적으로 추론 하기보다는 직접 평가하려고 한다. 원칙적으로 직접 평가는 장애 의 모든 결정요인인 신체손상, 기능, 환경 및 개인에 대해 동일한 고려를 한다. 장애 접근 방식은 가장 순수한 형태의 접근법으로 개인에 완전히 개별화되고 직접적인 증거를 근거로 사용한다.

이 장애 접근법이 이론적으로는 가장 적절하다고 인정되었지 만 유효하고 신뢰할 만한 장애평가를 위해 개인과 그 사람의 신 체적, 인간적, 성격적, 사회적, 정치적, 문화적 환경에 관한 모든 정보를 취합한다는 것이 현실적으로 불가능하므로 손상 접근법 이나 기능 제한 접근법이 더 바람직하다는 반론이 제기되고 있 다.

\section{3. 장애평가의 신뢰도 ${ }^{2)}$}

장애평가와 노동능력 평가는 의학적 지식으로 의학적 전문가가 해왔는데 의학적 기준은 객관적이고, 확실하며 신뢰받을 수 있다 고 믿어져 사회적으로 존중받아 왔다. 이를 통해서 장애평가의 정당성(legitimacy)과 확실성을 제공받아 왔고 의학적 전문가는 장애로 받는 혜택과 보상에 대한 접근을 적절히 통제할 수 있는 중요한 위치에 있다. 장애평가 절차에 신뢰도와 정당함이 있는지 여부는 몇 가지 관점으로 평가할 수 있다.

우선, ‘가양성' 또는 ‘가음성'을 최소화할 수 있도록 평가가 유 효해야 한다. 둘째, 동일한 규칙과 기준을 따르는 두 명의 평가자 가 같은 사람에 대해 동일한 평가를 수행할 수 있는 평가자 간 신 뢰도(inter-rater reliability)가 있어야 한다. 마지막으로 의사 결 정의 근거가 공개적으로 알려져 있고, 특히 적용되는 경우 독립 적으로 평가되도록 의사 결정은 투명하고 표준화되어야 한다. 이 런 전제가 있어야 장애평가가 공정하고 객관적인 증거에 근거한 것으로 받아들여질 수 있다.

장애는 복잡하고 측정하기가 어려워 이러한 신뢰성 기준은 실 제로 달성하기 쉽지 않다. 가장 자원이 충분하고 발달된 국가에 서도 오류가 발생하고 있어 미국과 영국에서 장애인의 사회보장 요구가 거절되어 소송에 이른 경우 그 중 $50 \%$ 에서 장애판정이 바뀌었다고 보고되고 있다.

또한 장애평가는 사회적 목적이나 정치적 의도에 의하여 변형 될 수 있는데 이는 의학적이나 노동력 상실에 근거한 고려뿐만 
아니라 사회적 고려에 의해서도 일어날 수 있다.

\section{4. 국내 및 외국의 장애평가법 \\ 1) 국내에서 사용되는 장애평가법}

(1) 국내 법률상 장애평가법 ${ }^{7}$

우리나라에는 현재 수십 개에 달하는 법률상 장애평가법이 발효 되어 실행되고 있는데 기준이 되고 있는 신체 장해등급은 1953 년 근로기준법 제정 시 처음 채택되었다. 이 신체 장해등급의 장 해항목과 장해보상액수의 산정 방법은 1911년 일본의 공장법에 서 유래한 1947년 일본노동기준법의 14 등급, 항목, 산정방법, 보 상일수와 거의 동일하다. 일본에서 제정 시 해당하는 등급의 노 동능력상실률의 산정은 장해의 정도를 의학적 평가가 아니라 보 상일수에 근거를 두고 있다. 즉 보상일수를 10 으로 나눈 숫자에 $\%$ 를 붙여 백분율화한 것으로 보이게 하여 평균 노동능력상실률 로 산정한 것이다. 현재 한국에서의 근로기준법과 산업재해보상 보험법에서 사용하고 있는 신체장해등급은 처음 제정 당시와 변 함없이 14 급으로 나누어져 있다. 그러므로 현행 근로기준법과 산 업재해보상보험법의 신체장해등급과 노동능력상실률은 의학적 신체 장애평가와 그에 따른 노동력 상실에 근거한 것이 아니라 1910년대의 일본 공장법 제정 당시의 장애에 대한 사회의 통념 에 따른 장해등급과 보상일수 지급기준에 비례하여 산정한 노동 력상실률임에도 우리나라의 대부분 신체 장애등급과 노동능력상 실률의 기본 근거로 차용되고 있다. 국가배상법, 학교안전공제회 의 신체장애등급과 노동능력상실률, 공무원 연금법의 신체장애 등급, 자동차손해배상 보장법의 후유장해의 구분, 광주민주화보 상법, 광주민주예우법, 공무원연금법, 사립학교교직원연금, 청소 년기본법, 화재재해보상법, 선원법, 어선 및 어선재해법 등이 동 일한 14 급으로 매우 유사하게 근로기준법의 체계를 차용하고 있 다. 국가유공자예우법은 장해등급을 7 등급으로, 의사상자예우법 과 장애인복지법은 6 등급으로, 국민연금법은 4 등급, 군인연금법 은 3 등급으로 일부 법률에서 변화시켜 분류하고 있다.

현재 대부분의 국내법상 장애평가법에서 사용되는 14 급의 체 계는 출발점이 된 시기가 100 여 년 전의 장애 개념으로서 각종 검사법이나 신체장해의 표현 및 분류방식이 현재의 의학적 수준 에 맞지 않고, 장해분류의 등급 수와 항목들이 단순하며, 특히 신 경계 및 정신장애에 있어서 등급별 장애내용의 표현이 불명확하 여 구별이 어렵다. 적용지침도 많이 개선되기는 하였으나 아직 문제점들이 존재하고 있다. 그러나 적용이 매우 간단하다는 장점 이 있고 실정법에 규정되어 있는 법 조항으로 명문화되어 있어 그 기준을 따를 수밖에 없다.

(2) 생명보험회사 장해등급

생명보험 후유장해 등급 분류는 76년부터 4차례 개정되어 2015 년 4월까지 사용되었고, 손해보험 후유장해 분류표는 98년 7월 이전과 이후로 나뉘어서 2 개의 다른 규정이 사용되었는데 장해
부위에 따라 11 가지로 나누고 각 부위에서 장해율을 세분하는 방법을 사용하였다.

생명 상해보험 통합 후유장해 분류표가 2005년 5월 발표되어 2018년 3월까지 사용되었고, 2018년 4월 1일부터 현재까지 개 정된 통합장해 분류가 사용되고 있다. 통합 후유장해 분류는 13 개 신체부위로 나누어서 각각의 장해판정 기준과 각각의 부위의 장해 정도에 따라 지급률을 정해 놓았다. ${ }^{8)}$

통합 후유장해 등급 분류는 장해판정 기준 등에 자세한 지침이 추가되어 있고 신체부위에 따라 장해 정도를 나열하여 급수에 따 라 다른 신체 부위의 장해 내용을 나열한 국가배상법, 자동차손 해배상 보장법, 산업재해보장보험법과 형식적으로 차이가 있으 나 실제 장해등급 항목 내용은 국가배상법의 장해 내용과 노동력 상실률, 산재보험 보상법의 장해 등급과 매우 유사하게 차용되고 있어 문제점과 한계는 유사하다고 할 수 있다.

(3) 맥브라이드법에 의한 장애평갈)

미국 캔자스 출신 정형외과 의사인 Earl D. McBride (18911975)가 “노동능력상실평가와 배상기능손상의 치료원칙 (Disability evaluation and principles of treatment of compensable injuries)"이라는 제목으로 1936년 초판을 발행한 후 $1938,1942,1948,1953,1963$ 년에 개정이 되었고 마지막 판 인 1963년 6판이 현재까지 기준으로 참고되고 있다. 1986년부 터 손해보험업계가 자동차보험대인배상에 차용하여 사용하기 시 작하였으며, 현재 법원에서도 이 방법을 신체장애로 인한 노동력 상실률 산정에 사용하고 있다. 19세기 말부터 20세기 초에 독일, 영국, 러시아에서 노동자에 대한 재해 보험, 장애 보상 계획 등이 발전하기 시작하였고 미국에서도 노동자 보상법이 적용되면서 미국 전역의 각 주마다 무원칙하고 다양하게 보상을 급여 주수로 정하였다. 맥브라이드는 각 주마다 통일되지 않은 보상을 Oklahoma 보상 기준을 바탕으로 정리하면서 전신대비 신체 각 부위 의 국소신체손상률(impairment of specific part)을 정하는 개 념을 도입하였고, 이는 후에 $\mathrm{AMA}$ 의 "영구적 신체장애평가지침 (guides to the evaluation of permanent impairment)"에 적 용되었다. 또한 국소신체손상률에서 직업표를 이용하여 장애부 위에 따른 가중치를 구하여 노동력상실률을 산정하였다.

여러 가지 문제점이 지적되고 있는데 첫 번째로 발간 당시와 현재의 발전한 의학적 현실과 괴리가 크고, 정형외과 분야의 장 애들은 비교적 자세하나 다른 분야의 경우 특히 뇌신경 분야의 경우에는 세세하지 못하여 적절한 장애평가 기준으로 사용하기 어렵다. 또한 명백한 오류가 발견되었고, 노동력 상실률 산정에 사용되는 직업표의 직종이 현재의 직업과는 달라서 적절한 적용 이 어렵고, 시행세칙이 자세하지 않아 평가자마다 다른 견해를 가질 수 있는 문제가 발생할 수 있다.

이러한 문제점에도 불구하고 이 평가 방법이 유일한 방법으로 사용되고 있는데 그 이유는 간편하고 신속하게 신체장애율과 노 
Soon-Hyuck Lee, et al.

동능력상실률을 함께 구할 수 있으며 숫자화되어 있어 매우 직관 적으로 비 전문가도 쉽게 이해 가능하다. 가장 중요한 이유는 법 원에서도 이 방법을 신체장해로 인한 노동력 상실률 산정에 사용 하고 있고, 오랜 기간 우리나라에서 사용되어 대부분의 장애평가 법의 근간으로 인용되었다는 것이다. 현재 우리나라에서 이를 대 체할 장애평가 기준은 제시되어 있지 않으므로 이 기준을 이용 하여 장애평가의 목적에 합당하도록 사용해야 하며, 이를 위해서 여러 문제점을 적절히 개선시켜야 하는 노력이 필요하다.

(4) 기타 국내외 장애평가

A. AMA의 "영구적 신체장애평가지침(guides to the evaluation of permanent impairment),"10): AMA에서는 1956년 신체 장애등급 위원회를 구성하고 1958년부터 1970년까지 무려 12 년에 걸쳐 각 분과학회 별로 Journal of the American Medical Association에 해당분야의 신체장애판정 평가 방법에 관하 여 13 개의 독립적인 논문으로 발표하였다. 이후 1971년에 60명 의 학자들의 공동저술로 “영구적 신체장애평가지침(guides to the evaluation of permanent impairment)"을 발행하였으며 1984 년에 개정판인 2판을 간행하였고, 1988년에 3판, 1994년 에 4판, 2000년에 5판이 발행되었다. 가장 최근인 2008년에 발 간된 제6판은 새로운 패러다임으로 $\mathrm{WHO}$ 에서 제안한 $\mathrm{ICF}$ 의 정 의와 용어를 차용하고, 장애율 산정과정의 일부로서 기능제한을 포함시켜 일상생활능력(activities of daily living)을 평가하는 단 순한 방법을 제시하면서, 진단명을 근거로 한 장애율 기준을 채 택하였다.

이는 개인의 신체장애를 객관적이고 근거 중심적인 가장 최신 의 임상적 그리고 과학적 지식을 총망라한 국제적 표준으로 알려 져 있어 미국 이외에 캐나다, 호주 등의 여러 나라에서 사용되고 있다.

그러나 최근에 발간된 6 판은 발간 8 개월만에 50 쪽에 달하는 많은 수정이 가해질 정도로 충분한 검토가 되지 않았으며 현재 미국에서도 16 개주에서는 AMA 지침을 사용치 않고 자신들만의 장애평가 지침을 가지고 있고, 사용하는 주에서도 3판, 4판, 5판, 6 판을 각 주마다 다르게 선택하여 사용하고 있는 실정이다.

$\mathrm{AMA}$ 지침은 손상접근 방식의 장애평가로 세계에서 가장 정 교하고 복잡하게 발전된 방법이고, 꾸준히 개정, 보완되고 있으 나 전술한 바의 문제점으로 비판 받고 있다. 또한 너무 방대하고 복잡하며 너무 세세하여 쉽게 사용하기 어려운 것은 물론 신체장 애율로만 수치가 산출되어 보상을 고려할 때 중요한 인자가 되는 직업이 가미된 노동능력장애가 산출되지 않는 결정적인 단점이 있다.

B. 대한의학회 장애평가기준 ${ }^{11)}$ : 우리나라에서 사용되고 있는 법률상 장애평가와 맥브라이드 법이 가진 한계에 대한 해법으로 2011년도 “대한의학회”에서 “장애평가기준(해설과 사례연구)" 란 책자를 발간하였다. 이는 AMA 신체장애평가 지침을 기본 골
격으로 한국 장애 현실과 장애 인지도 조사를 하고 한국 의료여 건을 고려하여 신체장애율을 평가하였다. 이후 한국 표준직업분 류 직업세세분류의 1,206 직종을 이용하여 판단한 “직업군”과 “환자의 해당 장애병명”을 참조하여 결정되는 노동능력상실지수 표에서 “노동능력상실지수”를 구하고, 마지막으로 신체장애율과 노동능력상실지수를 고려한 환자의 “노동능력상실률”을 구하는 방법을 채택하고 있다. 그러나 발간 직후부터 논란과 미비점이 있어 2013년 6월 개정작업을 결정하였고, 2016년 9월 개정판(2 판) “장애평가기준과 활용”을 발간하였으나 일부 내용에 대한 논 란이 지속되고 있고, 실제 적용 시에 여러 문제점이 노출되고 있 어 현재 사용되고 있지 않다.

이 방법은 $\mathrm{AMA}$ 장애평가 지침을 기본 골격으로 사용하였기 에 장점이자 단점인 복잡성으로 인하여 사용하기가 어려운 등의 $\mathrm{AMA}$ 장애평가 지침과 동일한 단점이 있으며, 이로 인하여 실제 장애평가 시 오류의 발생 가능성이 크고 그 결과에 대한 책임을 장애평가자에게 전가할 수 있는 문제점이 따를 것으로 예상된다. 또한 이를 적용하여 실제의 경우에 장애율을 산정해 본 전문가의 의견들은 맥브라이드 법에 의한 장애율과 유사한 정도가 평가되 는 경우가 대다수이나 상대적으로 매우 적게 산정되는 경우가 적 지 않게 나타날 수 있어 현재의 보상 규정에 동일하게 적용한다 면 피해자가 손해를 볼 수 있는 가능성에 대한 대책이 없다.

\section{요약및 제안}

우리나라에서 장애평가는 의료 전문가에게 그 권한과 책임이 있 는데, 이 때 기준이 되는 적절한 장애평가 방법을 확립하는 것은 매우 중요한 시발점이다.

현재 우리가 사용하는 장애평가 방법은 (1) 산재보험법, 국가배 상법 등에서 사용하는 국내법상 장애평가방법, (2) 생명 손해보험 회사의 후유장해등급, (3) 자동차보험과 법원에서 사용하는 맥브 라이드 노동능력상실 평가법이 있다. 이들이 적절한 장애평가 방 법인지 또는 대안이 가능한지에 대한 논의가 필요하다.

현재 대부분의 국내법상 장애평가법에 사용되는 14 급의 체계 와 보험회사의 통합 후유장해 등급 분류는 그 항목이 100여 년 전의 장애 개념으로 출발하여 신체장해의 표현 및 분류 방식이 현재의 의학적 수준에 맞지 않고, 장애분류의 등급 수와 항목들 이 단순하고 세밀하지 못하는 등의 문제점들이 있다. 법적 소송 이 있거나 자동차 상해 시 장애율 산정에 사용하고 있는 맥브라 이드 노동능력상실 평가법도 오래된 발행시기, 명백한 오류, 자 세하지 않은 시행 세칙, 직종에 따른 노동력 적용 등의 여러 부분 에 문제점이 있다는 사실에 모두가 공감하고 있다.

이러한 문제점에 대한 대안으로 대한의학회에서 AMA 신체 장애평가 지침을 골격으로 신체장애율을 평가하고, 직업에 따라 “노동능력상실율”을 구할 수 있는 “장애평가기준”을 발간하였으 
나 실제 적용 시에 문제점이 있어 현재 사용되고 있지 않다.

적절한 장애평가 방법이라는 것은 장애 종류와 정도를 잘 반영 하고, 사회가 감당할 수 있는 수준에 맞는 평가자의 시간과 노력 으로 일정 수준의 일관성, 신뢰도와 정당성이 담보되어야 한다. 우리 모두가 동의하는 논란의 여지가 없는 적절한 장애평가 방법 을 가지는 상황이 바람직하나 이를 이루는 것은 매우 지난한 일 이다. 첫째, 장애에 대한 개념은 변화하고 있으며 지속적으로 논 란의 대상이어서 장애가 실제 평가되는 방식에는 현재 괴리가 있 다. 둘째 장애평가의 주 관심 대상의 차이에 따른 적절한 장애평 가법에 이론적 논란이 있고 현실적 실현 가능성과도 차이가 있 다.

그러므로 새로운 평가방법의 제정은 새로운 논란을 야기할 가 능성이 커서 실제 사회적으로 인정되어 사용되기에는 많은 시간 이 필요하다.

$\mathrm{AMA}$ 평가 방법과 이를 기본 골격으로 사용한 대한의학회의 장애평가 안은 매우 정교한 장애평가 방법이지만 이것조차도 의 학적 기반 없이 전문가의 합의에 의한 한계와 과학적 문제점으로 비판 받고 있고 방대하고 복잡하며 너무 세세하여 쉽게 사용하기 어렵다.

또한 이러한 엄격하고 자세한 평가 규격은 일관성과 평가자 간 의 신뢰도를 높이지만 재량권이 상당히 제한되어 개별적인 차이 나 예외적인 상황을 무시하게 됨으로써 늘 최선의 방법이라 하기 어렵다.

대한의학회 장애평가 방법에서 평가자 간 오차 발생 가능성이 있고 이를 장애평가자의 오류와 책임이라고 전가할 수 있는 문제 점이 있으며, 여러 가지 문제점으로 인해 실제 사용되고 있지 않 다.

맥브라이드 법은 간편하고 비교적 신속하게 신체장애율과 노 동능력상실율을 함께 구할 수 있으며, 적정한 수준의 일관성, 신 뢰도가 유지되고 있다는 것이 일반적 의견이다. 여러 종류의 분 야 중에 특히 뇌신경 분야에서 내용이 세세하지 못하여 부족한 점이 크나 사지와 척추 분야는 비교적 자세하여 매우 유용하다.

현재 우리나라에서 맥브라이드의 노동능력상실 평가법을 대 신하는 새로운 평가방법이 제시되고, 인정받아 법률적으로 인용 되어 근거가 되기까지에는 현재로는 그 시기를 예상하기 어렵다. 또한 이에 근거하여 보상 금액이나 정책이 유지되었고, 다른 평 가법의 비교 근간으로 인용되어 왔는데 평가 방법이 바뀌면 또 다른 문제를 야기할 수 있으므로 바람직하지 않다.

이러한 이유로 현재로서 우리나라의 장애평가 방법에 대한 개 선방법은 또 다른 새로운 평가 기준 제시보다는 현재 법률적으로 인정되고 사용되고 있는 맥브라이드 평가방법의 원칙과 기준을 유지하고 사용하는 것이다.

그러나 맥브라이드의 노동능력상실 평가법은 현재의 의학적 수준과 많은 부분에서 분명한 차이가 있으며, 명백한 오류가 발
견되었고 또한 이 방법이 가지는 여러 제한과 한계가 있다는 주 장이 있으므로 그 동안 발견된 오류를 수정하고 현대의 의학적 수준에 합당한 평가가 가능하도록 변경하여야 하며 여러 제한과 문제점의 개선이 필요하다.

\section{CONFLICTS OF INTERERST}

The authors have nothing to disclose.

\section{ORCID}

Soon-Hyuck Lee, https://orcid.org/0000-0001-6846-6155

Se-Jin Park, https://orcid.org/0000-0002-3941-1857

Jin Hun Park, https://orcid.org/0000-0003-2175-2466

\section{REFERENCES}

1. World Health Organization (WHO), World Bank. World report on disability. Geneva, Washington, D.C.: WHO; 2011.

2. Bickenbach J, Posarac A, Cieza A, Kostanjsek N. Assessing disability in working age population: a paradigm shift from impairment and functional limitation to the disability approach. Washington, DC: World Bank; 2015 Jun. Report No.: ACS14124.

3. World Health Organization (WHO). International classification of impairments, disabilities, and handicaps: a manual of classification relating to the consequences of disease, published in accordance with resolution WHA29.35 of the Twenty-ninth World Health Assembly, May 1976. Geneva: WHO; 1980.

4. World Health Organization (WHO). ICIDH-2: International classification of impairments, disabilities, and handicaps-2. Geneva: WHO; 1997.

5. World Health Organization (WHO). International classification of functioning, disability and health: ICF. Geneva: WHO; 2001.

6. Bolderson H, Mabbett D, Hvinden B, van Oorschot WJH. Definitions of disability in Europe: a comparative analysis: final report. London: Brunel University; 2002.

7. Korean Orthopaedic Association. Disability evaluation. 2nd ed. Seoul: Seoul Med-Media Co; 2012. 32-33.

8. Financial Supervisory Service. Insurance Business Supervision Regulations: life insurance and non-life insurance integrated disability classification table [Internet]. Seoul: Finan- 
Soon-Hyuck Lee, et al.

cial Supervisory Service; 2018 [cited 2020 Jul 9]. Available from: https://m.blog.naver.com/PostView.nhn?blogId=hghnet $\& \operatorname{logNo}=221251138681$ \&proxyReferer $=$ https: $\% 2 \mathrm{~F} \% 2 \mathrm{Fw}$ ww.google.com\%2F.

9. McBride ED. Disability evaluation and principles of treatment of compensable injuries. 6th ed. Philadelphia: JB Lippinott; 1963.

10. Ranavaya M, Brigham CR. International use of the AMA
Guides to the evaluation of permanent impairment [Internet]. Chicago: American Medical Association; 2011 [cited 2020 Jul 9]. Available from: https://mayeyeclinic.sharepoint.com/Documents/International\%20Use\%20of\%20AMA\%20Guides. pdf.

11. Korean Academy of Medical Sciences. Guides for the evaluation of permanent impairment: commentary and case studies. Seoul: Bakyangsa Co; 2011. 


\section{맥브라이드노동능력상실평가법: 왜아직도 가장많이사용되는가? \\ 이순혁 - 박세진 * ・ 박진훈}

고려대학교 의과대학 고려대학교 안암병원 정형외과학교실, *성균관대학교 의과대학 강북삼성병원 정형외과학교실

장애의 개념은 명확하게 정의하기는 매우 어려운 일로 알려져 있고, 전 세계적으로 실제 장애가 평가되는 방식은 추정되는 장애의 개념과는 괴리가 있다. 무엇이 적절한 장애평가인지 제시하기는 어려운데 이는 장애의 종류와 정도를 잘 반영해야 하고, 사회가 감당할 수 있는 평가자의 시간과 비용으로 일정 수준의 일관성, 신뢰도와 정당성이 담보되어야 하기 때문이다. 장애평가에서 매 우 세세한 평가 규격을 사용하면 재량권이 제한되고, 이는 일관성과 신뢰도를 높이지만 개별적인 차이나 예외적인 상황을 무시하 는 결과가 발생한다. 장애평가법 중에 손상접근 방법은 전 세계적으로 가장 오래되고 널리 사용되는 방법으로 현재 우리나라에서 사용되고 있는 대부분의 장애평가 방법이 여기에 속한다. 맥브라이드법은 비교적 많은 시간을 쓰지 않고 신체장애율과 노동능력 상실률을 함께 구할 수 있으며, 현재 법원에서 노동력 상실 평가에 사용하고 있는 중요한 방법이다. 여러 오류와 논란이 있음이 잘 알려져 있어 이의 수정이 요구되지만 현재로서 우리나라의 장애평가 방법에 대한 개선안은 또 다른 새로운 평가 기준을 제시하기 보다는 현재 가장 널리 사용되고 있는 맥브라이드 평가 방법을 보완하여 사용하는 것이다. 본 종설에서는 장애의 개념과 장애평가 방법에 대하여 설명하고, 장애평가 방법의 종류를 소개하면서 맥브라이드의 노동능력상실 평가법이 아직도 유용하게 사용될 수 있는 당위성에 대하여 알아보고자 한다.

색인단어: 맥브라이드법, 배상, 장애, 장애평가

접수일 2020년 7월 18일 수정일 2020년 8월 16일 게재확정일 2020년 9월 8일 책임저자 박세진

03181 , 서울시 종로구 새문안로 29 , 성균관대학교 의과대학 강북삼성병원 정형외과학교실

TEL 02-2001-2168, FAX 02-2001-2176, E-mail qortn97@naver.com, ORCID https://orcid.org/0000-0002-3941-1857 